\title{
Overview on Untargeted Methods to Combat Food Frauds: A Focus on Fishery Products
}

\author{
Giuseppina M. Fiorino, ${ }^{1}$ Cristiano Garino, ${ }^{2}$ Marco Arlorio, ${ }^{2}$ Antonio F. Logrieco, ${ }^{1}$ \\ Ilario Losito, ${ }^{1,3}$ and Linda Monaci $\mathbb{D}^{1}$ \\ ${ }^{1}$ Institute of Sciences of Food Production, National Research Council (ISPA-CNR), Bari, Italy \\ ${ }^{2}$ Università degli Studi del Piemonte Orientale "Amedeo Avogadro" (UNIUPO), Novara, Italy \\ ${ }^{3}$ Department of Chemistry and SMART Interdepartment Research Center, University of Bari "Aldo Moro", \\ Via Orabona 4, 70126 Bari, Italy
}

Correspondence should be addressed to Linda Monaci; linda.monaci@ispa.cnr.it

Received 22 December 2017; Revised 19 February 2018; Accepted 21 February 2018; Published 11 April 2018

Academic Editor: Cristina Alamprese

Copyright (C) 2018 Giuseppina M. Fiorino et al. This is an open access article distributed under the Creative Commons Attribution License, which permits unrestricted use, distribution, and reproduction in any medium, provided the original work is properly cited.

\begin{abstract}
Authenticity and traceability of food products are of primary importance at all levels of the production process, from raw materials to finished products. Authentication is also a key aspect for accurate labeling of food, which is required to help consumers in selecting appropriate types of food products. With the aim of guaranteeing the authenticity of foods, various methodological approaches have been devised over the past years, mainly based on either targeted or untargeted analyses. In this review, a brief overview of current analytical methods tailored to authenticity studies, with special regard to fishery products, is provided. Focus is placed on untargeted methods that are attracting the interest of the analytical community thanks to their rapidity and high throughput; such methods enable a fast collection of "fingerprinting signals" referred to each authentic food, subsequently stored into large database for the construction of specific information repositories. In the present case, methods capable of detecting fish adulteration/substitution and involving sensory, physicochemical, DNA-based, chromatographic, and spectroscopic measurements, combined with chemometric tools, are illustrated and commented on.
\end{abstract}

\section{Introduction}

Since ancient times, food items have been manipulated and altered by humans to improve their quality properties. The number of food products placed on the market after being modified to improve their organoleptic properties and prolong their shelf-life has increased significantly in the last two centuries. Unfortunately, food manipulation for illegal purposes (e.g., by using low-quality ingredients in the manufacture of products that are instead commercialized as highquality food) has also become a widespread practice. Food adulteration, or "food fraud," occurs when an ingredient is partially or fully replaced with other food components unexpected from the consumer and whose presence is not indicated in the food label. Such a practice has become a concern on a global scale not only for consumers but also for producers and distributors and although it is not a new problem, quantifying its economic and public health impact is still a difficult task [1]. Globalization, urbanization, and consolidation of manufacturing are only some of the instances that contribute to the rapid growth of frauds. In particular, the demands of expanding urban population require more complex food production chains and global economics facilitate criminal activity, since remoteness and anonymity are often characteristics of some food supply chains [2]. On the other hand, the awareness of consumers on their purchases, regarding how, where, and when a food product has been produced, is growing year by year. These concerns were the drivers that prompted legislation to develop reliable procedures to assess the quality and safety requirements of the whole supply chain. The scandals concerning food security, such as bovine spongiform encephalopathy (BSE) or the recent discovery of the illegal introduction of horse into meat products, have attracted media and consumer attention and further 
TABLE 1: Types of food frauds [2].

\begin{tabular}{|c|c|}
\hline Types & Definition \\
\hline Adulteration & A component of the finished product is fraudulent \\
\hline Counterfeit & All aspects of the fraudulent product and packaging are fully replicated \\
\hline Diversion & The sale or distribution of legitimate products outside of intended markets \\
\hline Overrun & Legitimate product is made in excess of production agreements \\
\hline Simulation & Illegitimate product is designed to look like but does not exactly copy the legitimate product \\
\hline Tampering & Legitimate product and packaging are used in a fraudulent way \\
\hline Theft & Legitimate product is stolen and passed off as legitimately procured \\
\hline
\end{tabular}

contributed to the creation of food traceability tools. To address this concern, several analytical methods, aiming at tracing eventual contaminants and/or adulterating substances introduced into foods, have been devised over the last years.

In general, the developed methods can use either the microbiological or the chemical signals to spot any substitution or adulteration of a food product and can be classified as targeted and untargeted. In the first approach, specific and selected molecular markers are monitored during the analysis to assess the presence or the absence of compounds potentially related to food frauds. Untargeted methods are based on a holistic approach and intend to provide information about the whole food commodity typically as spectral fingerprint, giving a simplified and overall picture of the food under analysis. Afterwards, the entire dataset generated is elaborated by means of advanced statistical tools, providing information about the likelihood of adulteration. While a targeted approach is based on standardized procedures and methods, an untargeted analysis is deemed to be a rapid and high throughput approach, although it suffers from a lack in the standardization of the procedure.

Untargeted analysis is inherently able to provide a multitude of data, subsequently stored into large databases, thus enabling also retrospective analysis; thus it has gained an increasing relevance over the last years $[3,4]$. Different instrumental setups, aiming at standardizing analytical methodologies based on different detectors, have been explored in the context of untargeted analysis, yet additional work needs to be carried out in this field. Some guidelines have been recently issued by the US pharmacopeia to assist scientists in the development and validation of untargeted methods able to discriminate between a typical and an atypical sample [5].

The establishment of guidelines for untargeted methods is also among the objectives of the EU funded project Food Integrity, particularly of work package 18 (see the website https://secure.fera.defra.gov.uk/foodintegrity/index.cfm?sectionid=21). The present review intends to give a brief overview of fast and easy-to-use analytical techniques employed to assess authenticity of foods, with special reference to fishery products. In particular, both microbiological and chemical methods will be reviewed.

\section{Food Frauds under the Spotlight}

Food fraud is a wide term used to describe a widespread problem that appears to be constantly rising in the last decades. Since no statutory definition of the expression food fraud existed at that time, in May 2009, the US Food and Drug Administration (FDA) defined the Economically Motivated Adulteration (EMA) as: "...The fraudulent, intentional substitution or addition of a substance in a product for the purpose of increasing the apparent value of the product or reducing the cost of its production for economic gains." Spink and Moyer [2] distinguished seven types of food frauds as schematized in Table 1. According to the type of alteration made to the food product, frauds can have different wording, such as adulteration, counterfeiting, diversion of products outside the intended markets, overrun, simulation, tampering, and theft.

By definition, adulteration is a food product modification that results in a change of the identity and/or purity of the original ingredients, performed by substituting, diluting, or modifying them by physical or chemical means [6]. As an example, food can be adulterated by the introduction of an inert material or even of dangerous substances as such a practice can lead to an increase of the economic profits of the producer [45]. In the last 15 years, fraudulent events have occurred regularly, generating economic, ethical, safety, and socioreligious effects $[45,46]$. In this regard, Moore et al. described in their paper a comprehensive compilation of information about food fraud ingredients into a database [6]. The authors analyzed scholarly journals, media, and other reports to obtain useful information to develop the database. Figure 1 shows an overview of the ingredients most subjected to frauds.

Adulteration of foods is the most common type of food fraud encountered in the market. One of the most clamorous examples of food adulteration dates back to 2003, when chili peppers were altered through the addition of Sudan Red dye, resulting in a product with a lower cost [47]. Both Para Red and Sudan dyes are commonly used for nonfood purposes and their use in food and feed is illegal, since Sudan dyes have been classified as genotoxic and carcinogenic [48]. In 2008, dioxins, whose accumulation in the body causes a large array of potential and dangerous effects to human health, were detected in pork [49]. Another case that burst out in 2008 was melamine addition to milk powder [50]. Melamine is a nitrogen-rich organic base normally used in plastic industry and its addition in milk aimed at boosting the apparent protein content of milk with a consequent increase in profits [51]. More recently, in 2013, a food fraud consisting in the processing of beef-based products with horse meat emerged [52]. 


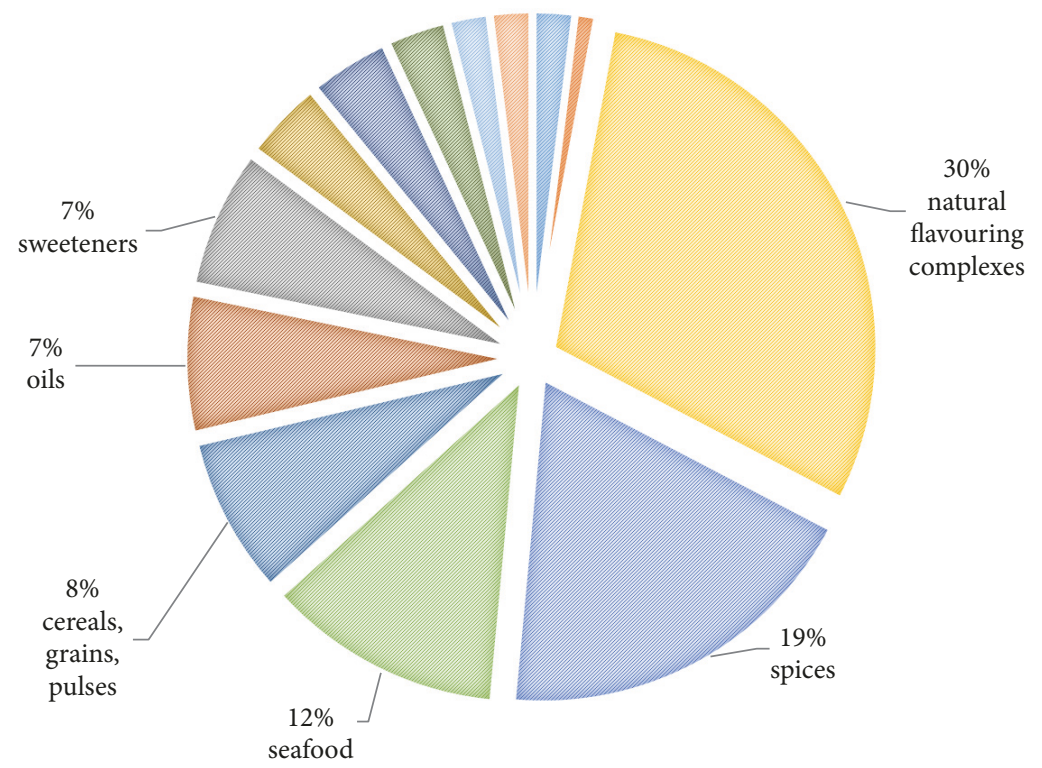

FIGURE 1: Comprehensive overview of food fraud ingredients referred to the period of 1980-2010, based on data obtained by Moore et al. [6] by analyzing scholarly journals, media, and other reports available.

Meat adulteration can infringe religious practices in Muslim and Jews populations that make their food choices on the base of the absence of pork and pork derivatives to ensure a porkfree diet. Likewise, Hindu populations avoid beef and beef products; therefore it is important to guarantee beef meat-free products [53].

Counterfeit alcohol is a well-known phenomenon, especially in cold countries. In the past years, several cases of methanol poisonings with counterfeit spirits have occurred in different regions of Russia, causing the death of many people and drawing attention once more to the problem of unrecorded alcohol consumption in the Russian Federation $[54,55]$.

Another food fraud case recently recorded affected roasted coffee. Coffee is one of the most popular beverages worldwide and adulteration of roasted coffee is common practice to reduce costs $[56,57]$. Illicit manipulations can concern not only the quality of beans in terms of species, geographical origin, and defective beans but also the addition of nondeclared natural substances (coffee husks and stems, corn, barley, chicory, wheat middlings, brown sugar, soybean, and rye) to coffee blends in order to make them less expensive [57].

\section{Analytical Methods for Food Authenticity and Traceability}

The ever-increasing food frauds and the sophisticated manipulation of food items have encouraged researchers to develop new and advanced analytical methods for food authenticity testing [58]. Nowadays, there is a demand for fast, accurate and easy-to-use approaches aimed at enriching the paucity of information derived from classical analytical methods and tracing new contaminants and adulterating substances added in food items. In general, food industries base their tests on fast and high throughput screening techniques, as in the case of spectroscopy combined with multivariate chemometric techniques for food quality testing [59-61]. Several studies reporting spectroscopic methods applied to various food commodities have been described in the literature. They represent one of the most powerful discriminating tools for food authenticity. In 2014, Nunes [62] applied near, mid, and Raman infrared spectroscopy to detect adulteration and to evaluate the quality of edible fats and oils, combining the final data with statistical multivariate analysis. In 2017, UV-VIS spectroscopy was used as a testing approach to distinguish pomegranate molasses from the date syrup [63]. In 2016, meat fraud characterized by nonmeat ingredient addition, including salts, carrageenan, maltodextrin, and collagen, was detected using ATR-FTIR spectroscopy and the purpose of this adulterant manipulation was to increase the water holding capacity in bovine meat [64]. In another paper, the same approach was used as a tool for unifloral honey authentication [65].

In 2017, an application of diffuse reflectance infrared Fourier transform spectroscopy (DRIFTS) and chemometric techniques was proposed to detect the illicit adulteration of saffron with six characteristic adulterants of plant origin [66]. Another paper reported the employment of a fast and relatively inexpensive method based on near-infrared (NIR) spectroscopy in combination with chemometrics for the discrimination between authentic South African and imported and/or adulterated honey [67]. More recently, a combination between total reflectance Fourier transform mid infrared (ATR-FTIR) spectroscopy and multivariate techniques has been applied to the straightforward quantification of the main fruits in four most-consumed nectar flavours in Brazil (grape, peach, orange, and passion fruit) adulterated with syrup, apple, and cashew [68]. 
As far as food traceability is concerned, DNA barcoding has been the election technique so far. For instance, DNA barcoding analyses were carried out for biological specimens attribution and identification of both raw materials and processed food [69]; for investigation of herbal product integrity and authenticity, excluding product substitution and contamination [70]; and for detection of mislabeled commercial fish products [71]. In this regard, a recent work proposed an analysis based on DNA barcoding to investigate labeling nonconformities on fishery products imported from third countries into the European Union [72]. Other authors utilized the principles of the DNA barcoding to detect mislabeling of fish in Japanese restaurants and fish markets in Brazil [73]. Furthermore, DNA barcoding shows high and promising potential to be used for species identification in processed products; for instance, in recent times, the ability of DNA barcoding to identify meat and poultry species in food products and to compare the results of full-length and mini-barcoding was proposed [74]. Although DNA barcoding was traditionally developed to identify fish and animal species, in a recent work, such approach has been adopted to detect adulteration of commercial sea buckthorn (Hippophae) products. Due to their putative health benefits and nutritional value, sea buckthorn berries have been used in about a variety of commercial products, such as food, fresh juice, beverages, herbs, nutraceutical products, and cosmetics. The presence of adulterants may lead to variation in efficacy of the bioactive components and possible loss of consumer trust. For this reason, there is a necessity for a rapid and accurate identification and authentication of Hippophae species in commercial products and DNA barcoding can address this issue [75].

In the food sector, mass spectrometry approaches have been applied to address food quality and authenticity. Mass spectrometry can be employed for the assessment of cheese safety; since during the dairy process microorganisms and mycotoxins can accumulate and affect final cheese quality, the use of HPLC-MS techniques allows the detection and quantification of selected mycotoxins [76]. Moreover, milk proteins constitute the major target for MS-based approaches to assess milk traceability and authenticity [77-80]. In this regard, a recent work published by Nardiello et al. shows potentials of a proteomic workflow based on multienzyme digestion followed by nano-LC-ESI-IT-MS/MS analysis for milk authenticity [81].

In a different application field, head-space solid-phase microextraction- (HS-SPME-) based method coupled to twodimensional gas chromatography-time-of-flight mass spectrometry $(\mathrm{GC} \times \mathrm{GC}-\mathrm{TOF}-\mathrm{MS})$ was applied for fast traceability of honey origin based on volatile pattern [82]. In the same years, a new analytical approach based on the coupling between Direct Analysis in Real Time (DART) ionization source and different types of mass spectrometers was proposed for authentication and traceability of several food items such as meat, beer, and olive oil [83-86]. DART coupled to high-resolution mass spectrometry (HRMS) was also applied for the discrimination among different types of milk obtained from various farm animal species (cow, goat, and sheep), the distinction between cows' milk produced in conventional and organic farming, and the detection of vegetable oil added to a milk-based product (soft cheese) [87]. In addition, such novel coupling based on a DART-QToF-MS analysis combined with chemometrics was applied for qualitative identification and confirmation of chemical components from authentic samples of four different species of cinnamon [88].

In conclusion, different analytical techniques can be used to promptly detect food frauds, and often the combination of data obtained with different techniques can be even more successful and promising.

\section{Frauds in the Seafood Market: General Aspects and Legislative Framework}

In the last years, increasing knowledge of the benefits related to fish consumption, especially for the high content in polyunsaturated fatty acids (the so-called PUFA), has contributed to a growing demand of either fresh or processed seafood products, with a consequent increase in the manipulation and adulteration of these foods. From a general point of view, the seafood supply chain is divided into two categories: edible lamellibranch molluscs (e.g., mussels and clams) and fishery products (e.g., fish and crustaceans). According to the specific product, the production may rely on capture if in the open sea (wild type species) and/or on aquaculture systems (farmed species). Both wild-type and farmed species represent an excellent source of nutritive components, but their chemical composition contributes to the high perishability of the product. Degradation processes like oxidation and hydrolysis which may occur during several steps of the supply chain like processing, transportation, and/or storage, and contaminants of biological (virus, bacteria, toxins, parasites) or chemical origin (heavy metals, mercury, and lead) can be a concern for the product quality and safety. Safety control measurements are different and depend on the type of capture, whether it occurred in open sea or in aquaculture tanks. Each stage along the fishery supply can pose a risk for fish safety; thus the cold chain, the traceability, and the labeling must not be interrupted in order to preserve consumers' health. As a further, relevant concern, label falsification and manipulations in the context of seafood products are continuously growing due to economic interests [89]. In addition, the consumption of products including an ingredient not mentioned in the label can cause serious and sometimes even fatal effects, as in the case of allergenic substances introduced into a food without the consumers' awareness [90].

In order to safeguard the consumers' health, a new labeling regulation for fishery and aquaculture products emphasizing the commercial and scientific name, the modality of production (capture or aquaculture), and the geographical origin of a seafood product has been issued in 2000 in the European Union [91]. This regulation provides a good and helpful set of information for the consumers who can be aware of the qualitative, geographic, and productive features of fishery items. Moreover, a system for the traceability of food (including fishery and aquaculture products) and feed producers has been set up by the European Food Safety Authority (EFSA) to assure food safety at all stages. In Regulation 882/2004, issued by the European Parliament and the 
Council on 29 April 2004, all the official controls (OCR) to be performed in order to ensure the verification of compliance with feed and food law, animal health, and animal welfare rules were detailed. In particular, article 53 of the regulation gives the Commission the mandate to recommend coordinated plans annually launched in accordance with a program; such plans should be organized on an ad hoc basis, in particular to establish the prevalence of hazards in feed, food, or animals [92]. The implementation of regulations on traceability and certificates of origin of fish products becomes more problematic when they concern foods imported from developing countries. In this regard, article 58 of the EC Regulation 1224/2009 requires that "all lots of fishery and aquaculture products must be traceable at all stages of production, processing and distribution, from collection to the retail stage." However, a recent study on the traceability requirements of seafood products applied in several countries has concluded that traceability of this category of products is still facing serious challenges, highlighting a lack of information on routine audits of traceability practices. In recent times, Regulation 1169/2011 of the European Parliament and of the Council, issued on 25 October 2011, concerning Food Information to Consumers (FIC), and Regulation (EU) 1379/2013 on the Common Market Organization of fishery and aquaculture products (CMO) gave a more extensive legislation framework about identification and labeling of fishery and aquaculture products $[93,94]$. In particular, regulation 1379/2013 contributed to the implementation of the traceability protocols for these products, indicating that "for the purpose of consumer protection, competent national authorities should make full use of available technology, including DNA testing, in order to deter operators from falsely labeling catches" [92].

Due to the increasing number of food frauds afflicting the European market with constantly increasing illicit profits [95], a big effort has been made in the European Union to limit falsification and adulteration of food commodities and seafood products are certainly among the latter. The fishery and aquaculture products were identified by the European Commission and Member States' experts as a highrisk commodity in terms of frauds, the most common fraud being fish species substitution [96]. To contrast frauds, some measurements were taken related to seafood products and in 2015 a control plan was coordinated at the European Union level to assess the presence on the market of mislabeled white fish [96]. The plan was part of the Commission follow-up of the horse meat crisis in 2013, including the systematic check of fraudulent activity in a certain sector as one of the actions. The type of sampling and the methods to be used for the official analysis were also specified in Recommendation 1558 issued in March 2015. In particular, samples were taken at different stages of the supply chain (for a total number of 3906 samples, belonging to over 150 white fish species) and subjected to analyses based on several biochemical techniques, namely, Isoelectric Focusing (IEF), Polymerase Chain Reaction-Restriction Fragment Length Polymorphism (PCRRFLP), DNA-barcoding, and Real Time-Polymerase Chain Reaction (RT-PCR) (uniplex or multiplex). The aggregated results can only give an idea of the situation concerning mislabeled white fish on the EU market. Actually, the adopted methods are just some of those available to assess fish authenticity, which will be described in detail in the next section.

In this context, the development of sensitive and fast analytical methods to assess authenticity, which are able to deliver a result in the shortest time possible, is an urgent need. The new methods have to integrate the traditional information derived from classical techniques with those obtained from a food fingerprinting analysis in order to build robust models associated with authentic foods.

\section{A Comprehensive Overview of Analytical Methods for Fish Authentication}

5.1. Biological Methods. Traditionally, microbiological methods have been applied to evaluate the presence or absence of microorganisms of public health interest in food products. If, on one hand, microbiological methodologies have been widely used for the detection of pathogenic microorganisms in fish, on the other hand microbiological data cannot provide complete information about the quality and freshness of a food product [7]. Another traditional and common method to assess fish quality is based on sensory analysis [8], whose limitation is the subjectivity of judgment, although the perceptive conditions are strictly controlled.

The analyses of fish and seafood have traditionally been performed using targeted species-specific methods based on electrophoretic or chromatographic separations or on immunological tests [97-99]. Some common methods include Isoelectric Focusing (IEF), capillary electrophoresis (CE), high-performance liquid chromatography (HPLC), and immunoassays. In 2002, Chen and Hwang [23] compared extracts obtained from sarcoplasmic, myofibrillar, SDS-soluble, and urea-soluble proteins by sodium dodecyl sulfatepolyacrylamide gel electrophoresis (SDS-PAGE) with Coomassie blue/silver double staining for species identification of puffer fish. An inappropriate labeling of several fish species, commercially sold under the general label "perch," was revealed using Isoelectric Focusing (IEF) and two-dimensional electrophoresis (2-DE) for the correct fish identification [24]. Moreover, two-dimensional electrophoresis (2$\mathrm{DE})$ associated with one-dimensional electrophoresis (1-DE) was used to discriminate wild-type from farmed cod muscle fillets under different modality of fish production [25].

However, since several proteins are thermolabile, these methods are not always applicable to thermally processed fish products.

Several immunological tests based on enzyme-linked immunosorbent assay (ELISA) tests have been also reported in literature and used to detect mislabeling of fish products [26-28]. ELISA may prove to be useful even in heat-sterilized products, although they are ineffective at differentiating loosely related species and require the development of antibodies directed against the specific protein of interest.

The use of DNA-based methods has a number of advantages over protein-based methods, including greater specificity, sensitivity, and reliable performance even with highly processed samples [100]. Although DNA molecules can also degrade during thermal treatments, they are more resistant 
than proteins; thus methodologies based on DNA analysis have been extensively reported in literature. The DNA-based methods present several advantages, such as high sensitivity, high specificity, large-scale throughput, and the possibility to apply different types of analyses on the same species (e.g., PCR, sequencing, cloning, and phylogenetic analysis) [101]. DNA-based methods have been widely applied, especially for the identification of fish species. Traditionally, identification of species was carried out through the evaluation of external characteristics. However, this morphologic evaluation is useful for the whole fish, but it is not applicable to processed fish products, normally exposed to filleting, beheading, and/or skinning [102]. The presence of species-specific polymorphisms due to the several mutations normally occurring in the genome [103] has encouraged researchers to develop a variety of DNA-based methods for fish species identification. Some methods include the use of PCR together with the restriction fragment length polymorphism (RFLP) [9], forensic information nucleotide sequencing (FINS) [10], polymorphism of the length of the amplified fragment (AFLP) [11], or single-strand conformational polymorphism (SSCP) [12, 13]. These techniques have been applied to the identification of numerous species of fish and seafood, including gadoids [14], flatfish [15, 16], salmonids [11, 104], scombroids [105, 106], sardines and anchovies [107, 108], eels [109], and mollusks $[110,111]$. More recently, a study based on the use of pyrosequencing as a rapid fish tool for species identification has been published [101]. DNA barcoding has also been widely used but especially for species identification [17-19]. A recent study based on the DNA barcoding approach was applied to reveal the incorrect labeling of imported fish products in China, amplifying the mitochondrial cytochrome $C$ oxidase 1 (COI) gene of the target fish to demonstrate the correspondence to the morphological identification [20]. More recently, DNA barcoding analysis and comparison of sequence of COI and Cytb gene fragments with the NCBI gene references and the BOLD databases have shown that $40 \%$ of processed fish products purchased in local market were correctly labeled, while $60 \%$ of the total processed fish products were recorded as mislabeled [21].

Since biological methods based on sequencing are timeand sample-consuming, in a recent study, a fast Short Amplicon High-Resolution Melting Analysis (SA-HRMA) method was developed for the authentication of Atlantic cod (Gadus morhua L.), representing one of the most consumed fish worldwide and a fish species exposed to fraudulent substitutions by a less valuable one [22].

It is important to stress that DNA-based molecular methods are generally unable to distinguish between organisms of the same species which come from geographically close populations due to the gene flow between these populations $[112,113]$. An exception might be represented by the PCRdenaturing gradient gel electrophoresis (DGGE) performed on the bacterial communities living on the surface of fish products, which has been to date the most widely used molecular tool for the determination of geographic origin [114-117]. The rationale behind this method lies in the fact that different bacterial communities are associated with organisms of different nature and geographical position. With the exception of this molecular technique, geochemical tools, in particular the fingerprinting of trace elements (TEF), are generally employed to distinguish entire populations using the elementary profile of mineral structures $[118,119]$. The TEF is a reliable and accurate method, especially to distinguish samples belonging to geographically close populations [120-122].

5.2. Chemical Methods. Other than molecular methods, several strategies based on spectroscopic techniques have been adopted to verify the integrity and/or assess the contamination of seafood products. In 2007, Smulevich and collaborators investigated the presence of carbon monoxide (CO) in tuna fish, fresh or frozen, by optical spectroscopy, since carbon monoxide is used for illegal stabilization of fresh colour in meat and fish [123].

The detection of possible falsification, fraudulent alterations, and substitution of high-quality fish with lower valuable species can be ensured by innovative and straightforward methods. Near-infrared (NIR) spectroscopy and imaging techniques represent useful technologies adopted for the evaluation of fish quality thanks to fast speed, noninvasiveness, ease of use, and simple sample preparation [29]. Several Authors have applied NIR spectroscopy to solve adulteration issues. Uddin and coauthors described NIR spectroscopy analysis combined with multivariate statistic data treatment applied to the differentiation of fresh from frozen fish fillets, since a fraudulent substitution of fresh costly fish with frozen and less valuable fish often occurs [30]. Near-infrared spectroscopy (NIRS) coupled with different chemometric techniques was applied for discriminating wild from farmed sea bass samples [31]. In conclusion, it was found that NIR spectroscopic-based analysis can turn out to be a reliable tool for fish authentication in terms of mislabeling and fraudulent species substitutions, thus limiting the risk on human health [32]. A work published in 2018 demonstrated the capability of a handheld NIR device in distinguishing fillets and patties of Atlantic cod (Gadus morhua) from those of haddock (Melanogrammus aeglefinus) in comparison with a FT-NIR benchtop spectrometer, helping in improving commercial fraud fight [33].

Untargeted approaches have also been applied to specific issues related to fish authentication.

Lipid analysis has traditionally been important in biology and chemistry, because lipids are essential components of cell membranes and tissues; therefore they have often been used as biomarkers [124]. The composition of fatty acids (FA) contributes to the regulation of the fluidity of cell membranes and is known to adapt to physical-chemical conditions of the environment [125]. Furthermore, the diet of aquatic organisms varies according to the habitat and the ecosystem, thus influencing the composition of FA in the organism $[126,127]$. In particular, organisms obtained by capture may have a quite different feeding regime compared to those farmed in aquacultural plants. In the work of Masoum and colleagues, fish oils were analyzed by NMR analysis to discriminate between wild and farmed salmons, and Support Vector Machines (SVMs) were used as a novel learning machine in the authentication of the fish origin [128]. The method proved 
to be able to distinguish correctly between wild and farmed salmon and was able to assign the correct country of origin in $95 \%$ of the cases. In another study, Bayesian Belief Networks $(\mathrm{BBN})$ for the classification of wild versus farmed Atlantic salmon (Salmo salar L.) were applied to a dataset based on the distribution, obtained using gas chromatography of 12 fatty acids (FAs), derived from 131 salmon samples with several geographical origins [129]. To minimize the effect of seasonality associated with the diet, it is important to use, for the analysis, tissues rich in polar lipids, such as the adductor muscle of bivalves, which are less prone to changes in the diet [130, 131]. Muscle lipids from 195 Atlantic salmons of known origin (wild and farmed salmon from Norway, Scotland, Canada, Iceland, Ireland, the Faroe Islands, and Tasmania) were analyzed by ${ }^{13} \mathrm{C}$ NMR spectroscopy and the resulting data were processed by multivariate analysis. Both probabilistic neural networks (PNN) and support vector machines (SVM) provided excellent discrimination (98.5 and 100.0\%, resp.) between wild and farmed salmon. Discrimination with respect to geographical origin was somewhat more difficult, with correct classification rates ranging from 82.2 to $99.3 \%$ by PNN and SVM, respectively [132].

One of the main limitations of biochemical analysis is that lipids are susceptible to oxidation, which prevents their monitoring in processed products. A different example of nontargeted approach applied to the differentiation of wild and farmed salmons, not based on lipid fingerprinting, was described in 2010 by Anderson et al. [133]. In this work, the authors reported the chemical profiling of two populations of salmons performed by combining elemental profiles or $\mathrm{C}$ and $\mathrm{N}$ stable isotope ratios with various modeling approaches. Isotopic and compositional analyses of carbon and nitrogen were performed using mass spectrometry as an alternative fingerprinting technique. All the developed predictive models performed well, with the percentage of samples classified correctly, depending on the particular choice of model and evaluation method used.

Among other analytical approaches, mass spectrometry represents a potentially powerful and reliable technique for fish authentication, yet it is still underexploited. In 2014, a detailed characterization of fish-specific protein expression profiles was obtained by coupling two-dimensional electrophoresis with tandem mass spectrometry [36]. In the same year, the use of isotope ratio mass spectrometry (IRMS) was employed to detect the mislabeling of fish origin [43], since IRMS is the technique of election for discriminating the geographical origin of a product. IRMS was also applied to the discrimination between wild and farmed Atlantic salmon, so that farmed salmon escaping from aquaculture sites could be promptly identified [44]. In 2008, Mazzeo et al. [39] used the MALDI-TOF-MS analysis of protein extracts from muscle tissue to draw molecular profiles that could be used to distinguish fish species.

More recently, Wulff et al. [37] worked on the development of a new robust, proteome-wide tandem mass spectrometry method based on a simple and standardized workflow, which considers protein extraction, digestion, and data analysis for fish authenticity.

In 2017, a new mass spectrometry technique based on rapid evaporative ionization (REIMS) was applied to determine the fish species of the samples in real time, unlike most forms of analytical systems employed for such studies. Additionally, this study demonstrated the possibility of distinguishing between different catch methods within a species, an aspect of fish fraud which is well known but has never been previously reported [38]. Ever in 2017, a protein fingerprint database of common food fish obtained by application of MALDITOF MS was developed [40]. The database contained protein patterns of common food fish prone to substitution. Indeed, the substitution rate of fish is often dependent on the species and particular species are subjected to more substitutions compared to other species [40]. Ever in recent times, the application of MALDI TOF MS was adopted to evaluate the efficiency of various protocols for fish species identification [41].

Other adulterations concern fish quality and freshness. According to usual recommendations, "fresh" fish can be sold as "fresh" fish for human consumption up to 10 days after fishing [42]. In order to prevent food fraud and health risks for consumers resulting from spoiled fish, a method based on MALDI-TOF MS was employed for the determination of the freshness and the identity of two trout species (rainbow and brown trout), choosing the vitreous body of the eye as sample material [42]. MALDI-TOF MS analysis enabled the differentiation between storage periods and the interspecies identification of brown and rainbow trout.

In conclusion, MALDI-TOF MS has a potential to be used as an alternative to other DNA techniques herein presented aiming at exploring genomic features or, in combination with them, to reveal fish fraudulent substitutions.

An overview of the major biological and chemical analytical methods available for fish authentication is given in Table 2.

\section{Class-Modeling Methods for the Assessment of Fishery Products Authenticity}

As already emphasized throughout this review, chemometric approaches represent a fundamental tool for the assessment of food authenticity, especially when an untargeted analytical method is applied to food characterization. A specific ensemble of chemometric methods that have proved to be quite reliable when applied to food authenticity assessment is represented by the so-called class-modeling methods $[134,135]$. As a general concept, these methods verify the compliance with the specification of a class (e.g., a geographical origin for a food) starting from the definition of a multivariate enclosed space for samples authentically belonging to the class of interest. In many cases, they use the result of exploratory techniques, like Principal Component Analysis, as a starting point. SIMCA (soft independent modeling of class analogy) [136], UNEQ (unequal dispersed classes) [137], and potential functions techniques [138] can be cited among classmodeling methods that have been extensively exploited for the assessment of authenticity or adulteration of several food commodities, including olive oil, honey, alcoholic beverages (wine, beer, and distilled beverages), soft drinks, coffee, milk, cheese, meat, and vegetables (see $[135,139]$ and references cited therein). Application of class-modeling methods to 
TABLE 2: Overview of biological and chemical analytical methods developed to assess fish authenticity.

\begin{tabular}{|c|c|c|c|}
\hline & Technique & Purpose & References \\
\hline \multirow{9}{*}{ Biological methods } & Microbiological methods & $\begin{array}{c}\text { Evaluation of the presence/absence of } \\
\text { pathogenic microorganisms for fish } \\
\text { quality }\end{array}$ & [7] \\
\hline & Sensory analysis & $\begin{array}{l}\text { Evaluation of qualitative characteristics of } \\
\text { fish using the sensorial skills }\end{array}$ & [8] \\
\hline & $\begin{array}{l}\text { PCR-SSCP, PCR RFLP, } \\
\text { FINS, pyrosequencing } \\
\text { analysis }\end{array}$ & Identification of fish species & {$[9-16]$} \\
\hline & DNA barcoding & $\begin{array}{l}\text { Identification of fish species; detection of } \\
\text { fish mislabeling }\end{array}$ & {$[17-21]$} \\
\hline & $\begin{array}{l}\text { Short Amplicon High } \\
\text { Resolution Melting } \\
\text { Analysis (SA-HRMA) }\end{array}$ & $\begin{array}{c}\text { Fraudulent substitutions of high } \\
\text { consumed fish species with less valuable } \\
\text { ones }\end{array}$ & {$[22]$} \\
\hline & $\begin{array}{l}\text { SDS-PAGE with Coomassie } \\
\text { blue/silver double staining }\end{array}$ & Identification of fish species & {$[23]$} \\
\hline & $\begin{array}{l}\text { Isoelectric focusing (IEF) } \\
\text { and two-dimensional } \\
\text { electrophoresis (2-DE) }\end{array}$ & Detection of fish mislabeling & {$[24]$} \\
\hline & $\begin{array}{l}\text { Two-dimensional } \\
\text { electrophoresis }(2-\mathrm{DE}) \text { and } \\
\text { one-dimensional } \\
\text { electrophoresis (1-DE) }\end{array}$ & $\begin{array}{l}\text { Discrimination of wild type from farmed } \\
\text { fish fillets }\end{array}$ & {$[25]$} \\
\hline & $\begin{array}{l}\text { Enzyme-linked } \\
\text { immunosorbent assay } \\
\text { (ELISA) }\end{array}$ & Detection of fish mislabeling & [26-28] \\
\hline \multirow{5}{*}{$\begin{array}{l}\text { Chemical } \\
\text { methods }\end{array}$} & $\begin{array}{l}\text { Near-infrared spectroscopy } \\
\text { (NIRS) }\end{array}$ & $\begin{array}{l}\text { Evaluation of fish quality; discrimination } \\
\text { of wild type from farmed fish; detection of } \\
\text { fish mislabeling; fraudulent species } \\
\text { substitutions; differentiation between } \\
\text { fresh/frozen fish fillets }\end{array}$ & [29-35] \\
\hline & Tandem mass spectrometry & $\begin{array}{l}\text { Detection of seafood traceability, food } \\
\text { safety, risk management, and } \\
\text { authentication analysis }\end{array}$ & {$[36,37]$} \\
\hline & REIMS & $\begin{array}{l}\text { Identification of fish species; distinction } \\
\text { among different catch methods within a } \\
\text { fish species }\end{array}$ & {$[38]$} \\
\hline & MALDI-TOF-MS analysis & $\begin{array}{c}\text { Detection of species-specific biomarker } \\
\text { for fish authentication; identification of } \\
\text { fish species and substitutions; evaluation } \\
\text { of fish freshness }\end{array}$ & {$[39-42]$} \\
\hline & $\begin{array}{c}\text { Isotope ratio mass } \\
\text { spectrometry (IRMS); } \\
\text { stable isotopes analysis }\end{array}$ & $\begin{array}{c}\text { Detection of mislabeling of fish origin; } \\
\text { discrimination of wild type from farmed } \\
\text { fish }\end{array}$ & {$[43,44]$} \\
\hline
\end{tabular}

the assessment of authenticity of fishery products has been limited so far. In particular, SIMCA has been applied, in comparison with Linear Discriminant Analysis (LDA), to distinguish more valuable fish species, namely, red mullet and plaice, from cheaper ones (Atlantic mulled and flounder) and even to recognize Atlantic mullet fresh fillets from frozenthawed ones, starting from FT-NIR data in both cases [34]. A similar approach has been adopted more recently in another study based on FT-NIR data, whose goal was to distinguish fillets and patties of Atlantic cod from those of haddock [33]. Multivariate statistical tools comparing Hierarchical Cluster Analysis (HCA), PCA, and PLS applied to the analysis of the volatile organic fraction have been recently exploited for the identification of seafood spoilage indicators [140].

In conclusion, it is reasonable to hypothesize that further applications of class-modeling methods to the assessment of seafood authenticity, starting from data obtained using biochemical or mass spectrometric methods, will be reported in the future.

\section{Conclusions}

The global issue of food fraud, affecting consumers, producers, and distributors, has generated the urgent need to have 
at disposal sensitive and standardized techniques capable of a prompt detection of foods not complying with what was declared. In this review, we provided an overview of the current methods to assess authenticity of foods. Particular emphasis was given to seafood products, since fish substitution or incorrect storage or transportation of such perishable products is a frequent problem that might negatively impact both the quality and safety of fish. Methods most widely used for detection of fish adulteration/substitution, based on sensory, physicochemical, DNA-based, MS-based, and spectroscopic analyses combined with chemometric tools, have been herein reviewed and discussed.

\section{Conflicts of Interest}

The authors declare that they have no conflicts of interest.

\section{Acknowledgments}

This research has received funding from the European Union's Seventh Framework Programme for research, technological development, and demonstration under Grant Agreement no. 613688.

\section{References}

[1] M. I. López, E. Trullols, M. P. Callao, and I. Ruisánchez, "Multivariate screening in food adulteration: Untargeted versus targeted modelling," Food Chemistry, vol. 147, pp. 177-181, 2014.

[2] J. Spink and D. C. Moyer, Backgrounder: Defining the public health threat of food fraud, vol. 1, National Center for Food Protection and Defense, Minneapolis, MN, USA, 2011.

[3] J. Riedl, S. Esslinger, and C. Fauhl-Hassek, "Review of validation and reporting of non-targeted fingerprinting approaches for food authentication," Analytica Chimica Acta, vol. 885, pp. 1732, 2015.

[4] S. Esslinger, J. Riedl, and C. Fauhl-Hassek, "Potential and limitations of non-targeted fingerprinting for authentication of food in official control," Food Research International, vol. 60, pp. 189204, 2014.

[5] U.S. Pharmacopeial Convention, "Guidance on developing and validating non-targeted methods for adulteration detection," Appendix XVIII, 2016.

[6] J. C. Moore, J. Spink, and M. Lipp, "Development and application of a database of food ingredient fraud and economically motivated adulteration from 1980 to 2010," Journal of Food Science, vol. 77, no. 4, pp. R118-R126, 2012.

[7] A. M. Herrero, "Raman spectroscopy a promising technique for quality assessment of meat and fish: A review," Food Chemistry, vol. 107, no. 4, pp. 1642-1651, 2008.

[8] G. Ólafsdóttir, E. Martinsdóttir, J. Oehlenschläger et al., "Methods to evaluate fish freshness in research and industry," Trends in Food Science \& Technology, vol. 8, no. 8, pp. 258-265, 1997.

[9] G. L. Hold, V. J. Russell, S. E. Pryde et al., "Validation of a PCRRFLP based method for the identification of salmon species in food products," European Food Research and Technology, vol. 212, no. 3, pp. 385-389, 2001.

[10] S. E. Bartlett and W. S. Davidson, "FINS (Forensically Informative Nucleotide Sequencing): A procedure for identifying the animal origin of biological specimens," BioTechniques, vol. 12, no. 3, pp. 408-411, 1992.

[11] J. Zhang and Z. Cai, "Differentiation of the rainbow trout (Oncorhynchus mykiss) from Atlantic salmon (Salmon salar) by the AFLP-derived SCAR," European Food Research and Technology, vol. 223, no. 3, pp. 413-417, 2006.

[12] H. Rehbein, I. M. Mackie, S. Pryde et al., "Fish species identification in canned tuna by PCR-SSCP: Validation by a collaborative study and investigation of intra-species variability of the DNApatterns," Food Chemistry, vol. 64, no. 2, pp. 263-268, 1999.

[13] H. Rehbein, G. Kress, and T. Schmidt, "Application of PCRSSCP to species identification of fishery products," Journal of the Science of Food and Agriculture, vol. 74, no. 1, pp. 35-41, 1997.

[14] T. Akasaki, T. Yanagimoto, K. Yamakami, H. Tomonaga, and S. Sato, "Species identification and PCR-RFLP analysis of cytochrome b gene in cod fish (order Gadiformes) products," Journal of Food Science, vol. 71, no. 3, pp. C190-C195, 2006.

[15] A. Sanjuan and A. S. Comesaña, "Molecular identification of nine commercial flatfish species by polymerase chain reactionrestriction fragment length polymorphism analysis of a segment of the cytochrome b region," Journal of Food Protection, vol. 65, no. 6, pp. 1016-1023, 2002.

[16] A. S. Comesana, P. Abella, and A. Sanjuan, "Molecular identification of five commercial flatfish species by PCR-RFLP analysis of a 12S rRNA gene fragment," Journal of the Science of Food and Agriculture, vol. 83, no. 8, pp. 752-759, 2003.

[17] A. D. Pinto, P. D. Pinto, V. Terio et al., "DNA barcoding for detecting market substitution in salted cod fillets and battered cod chunks," Food Chemistry, vol. 141, no. 3, pp. 1757-1762, 2013.

[18] A. Armani, L. Guardone, L. Castigliego et al., "DNA and MiniDNA barcoding for the identification of Porgies species (family Sparidae) of commercial interest on the international market," Food Control, vol. 50, pp. 589-596, 2015.

[19] D. C. Carvalho, R. M. Palhares, M. G. Drummond, and T. B. Frigo, "DNA Barcoding identification of commercialized seafood in South Brazil: a governmental regulatory forensic program," Food Control, vol. 50, pp. 784-788, 2015.

[20] S. Yan, G. Lai, L. Li, H. Xiao, M. Zhao, and M. Wang, "DNA barcoding reveals mislabeling of imported fish products in Nansha new port of Guangzhou, Guangdong province, China," Food Chemistry, vol. 202, pp. 116-119, 2016.

[21] T. T. T. Ha, N. T. Huong, N. P. Hung, and Y. Guiguen, "Species Identification Using DNA Barcoding on Processed Panga Catfish Products in Viet Nam Revealed Important Mislabeling," Turkish Journal of Fisheries and Aquatic Sciences, vol. 18, no. 3, pp. 457-462, 2018.

[22] C. Tomás, I. M. P. L. V. O. Ferreira, and M. A. Faria, "Codfish authentication by a fast Short Amplicon High Resolution Melting Analysis (SA-HRMA) method," Food Control, vol. 71, pp. 255-263, 2017.

[23] T.-Y. Chen and D.-F. Hwang, "Electrophoretic identification of muscle proteins in 7 puffer species," Journal of Food Science, vol. 67, no. 3, pp. 936-942, 2002.

[24] A. Berrini, V. Tepedino, V. Borromeo, and C. Secchi, "Identification of freshwater fish commercially labelled "perch" by isoelectric focusing and two-dimensional electrophoresis," Food Chemistry, vol. 96, no. 1, pp. 163-168, 2006.

[25] I. Martinez, R. Šližyte, and E. Daukšas, "High resolution twodimensional electrophoresis as a tool to differentiate wild from farmed cod (Gadus morhua) and to assess the protein composition of klipfish," Food Chemistry, vol. 102, no. 2, pp. 504-510, 2007. 
[26] L. Asensio, I. González, M. A. Pavón, T. García, and R. Martín, "An indirect ELISA and a PCR technique for the detection of Grouper (Epinephelus marginatus) mislabeling," Food Additives and Contaminants - Part A Chemistry, Analysis, Control, Exposure and Risk Assessment, vol. 25, no. 6, pp. 677-683, 2008.

[27] E. Carrera, M. Terni, A. Montero, T. García, I. González, and R. Martín, "ELISA-based detection of mislabeled albacore (Thunnus alalunga) fresh and frozen fish fillets," Food and Agricultural Immunology, vol. 25, no. 4, pp. 569-577, 2014.

[28] L. Taboada, A. Sánchez, A. Velasco, F. J. Santaclara, R. I. PérezMartín, and C. G. Sotelo, "Identification of Atlantic cod (Gadus morhua), ling (Molva molva), and Alaska pollock (Gadus chalcogrammus) by PCR-ELISA using duplex PCR," Journal of Agricultural and Food Chemistry, vol. 62, no. 24, pp. 5699-5706, 2014.

[29] D. Liu, X.-A. Zeng, and D.-W. Sun, "NIR spectroscopy and imaging techniques for evaluation of fish quality - A review," Applied Spectroscopy Reviews, vol. 48, no. 8, pp. 609-628, 2013.

[30] M. Uddin, E. Okazaki, S. Turza, Y. Yumiko, M. Tanaka, and Y. Fukuda, "Non-destructive visible/NIR spectroscopy for differentiation of fresh and frozen-thawed fish," Journal of Food Science, vol. 70, no. 8, pp. C506-C510, 2005.

[31] M. Ottavian, P. Facco, L. Fasolato et al., "Use of near-infrared spectroscopy for fast fraud detection in seafood: Application to the authentication of wild European sea bass (Dicentrarchus labrax)," Journal of Agricultural and Food Chemistry, vol. 60, no. 2, pp. 639-648, 2012.

[32] N. O’Brien, C. A. Hulse, F. Pfeifer, and H. W. Siesler, "Near infrared spectroscopic authentication of seafood," Journal of Near Infrared Spectroscopy, vol. 21, no. 4, pp. 299-305, 2013.

[33] S. Grassi, E. Casiraghi, and C. Alamprese, "Handheld NIR device: A non-targeted approach to assess authenticity of fish fillets and patties," Food Chemistry, vol. 243, pp. 382-388, 2018.

[34] C. Alamprese and E. Casiraghi, "Application of FT-NIR and FTIR spectroscopy to fish fillet authentication," LWT-Food Science and Technology, vol. 63, no. 1, pp. 720-725, 2015.

[35] A. Dalle Zotte, M. Ottavian, A. Concollato, L. Serva, R. Martelli, and G. Parisi, "Authentication of raw and cooked freezedried rainbow trout (Oncorhynchus mykiss) by means of near infrared spectroscopy and data fusion," Food Research International, vol. 60, pp. 180-188, 2014.

[36] G. Terova, S. Pisanu, T. Roggio, E. Preziosa, M. Saroglia, and M. F. Addis, "Proteomic profiling of sea bass muscle by two-dimensional gel electrophoresis and tandem mass spectrometry," Fish Physiology and Biochemistry, vol. 40, no. 1, pp. 311-322, 2014.

[37] T. Wulff, M. E. Nielsen, A. M. Deelder, F. Jessen, and M. Palmblad, "Authentication of fish products by large-scale comparison of tandem mass spectra," Journal of Proteome Research, vol. 12, no. 11, pp. 5253-5259, 2013.

[38] C. Black, O. P. Chevallier, S. A. Haughey et al., "A real time metabolomic profiling approach to detecting fish fraud using rapid evaporative ionisation mass spectrometry," Metabolomics, vol. 13, no. 12, 2017.

[39] M. F. Mazzeo, B. De Giulio, G. Guerriero et al., "Fish authentication by MALDI-TOF mass spectrometry," Journal of Agricultural and Food Chemistry, vol. 56, no. 23, pp. 11071-11076, 2008.

[40] A. Stahl and U. Schröder, "Development of a MALDI-TOF MS-Based Protein Fingerprint Database of Common Food Fish Allowing Fast and Reliable Identification of Fraud and Substitution," Journal of Agricultural and Food Chemistry, vol. 65, no. 34, pp. 7519-7527, 2017.
[41] G. Spielmann, I. Huber, M. Maggipinto, G. Haszprunar, U. Busch, and M. Pavlovic, "Comparison of five preparatory protocols for fish species identification using MALDI-TOF MS," European Food Research and Technology, pp. 1-10, 2017.

[42] S. Ulrich, P.-M. Beindorf, B. Biermaier, K. Schwaiger, M. Gareis, and C. Gottschalk, "A novel approach for the determination of freshness and identity of trouts by MALDI-TOF mass spectrometry," Food Control, vol. 80, pp. 281-289, 2017.

[43] J. S. Rossier, V. Maury, B. De Voogd, and E. Pfammatter, "Use of isotope ratio mass spectrometry (IRMS) determination (18O/ $16 \mathrm{O})$ to assess the local origin of fish and asparagus in western Switzerland," CHIMIA International Journal for Chemistry, vol. 68, no. 10, pp. 696-700, 2014.

[44] J. B. Dempson and M. Power, "Use of stable isotopes to distinguish farmed from wild Atlantic salmon, Salmon salar," Ecology of Freshwater Fish, vol. 13, no. 3, pp. 176-184, 2004.

[45] M. Kamruzzaman, "Food adulteration and authenticity" in Food Safety, pp. 127-148, Springer International Publishing, Cham, Switzerland, 2016.

[46] C. Alamprese, M. Casale, N. Sinelli, S. Lanteri, and E. Casiraghi, "Detection of minced beef adulteration with turkey meat by UV-vis, NIR and MIR spectroscopy," LWT-Food Science and Technology, vol. 53, no. 1, pp. 225-232, 2013.

[47] European Commission, Questions and Answers on Sudan Dyes Contamination of Certain Food Products, European Commission, Brussels, Belgium, 2005.

[48] G. A. Kleter, A. Prandini, L. Filippi, and H. J. P. Marvin, "Identification of potentially emerging food safety issues by analysis of reports published by the European Community's Rapid Alert System for Food and Feed (RASFF) during a four-year period," Food and Chemical Toxicology, vol. 47, no. 5, pp. 932-950, 2009.

[49] L. Heres, R. Hoogenboom, R. Herbes, W. Traag, and B. Urlings, "Tracing and analytical results of the dioxin contamination incident in 2008 originating from the Republic of Ireland," Food Additives and Contaminants - Part A Chemistry, Analysis, Control, Exposure and Risk Assessment, vol. 27, no. 12, pp. 1733$1744,2010$.

[50] S. V. Smirnov, "Melamine analysis in liquid milk by simple and robust neural network based method," in Proceedings of the 2011 Third International Workshop on Education Technology and Computer Science, vol. 2, pp. 19-22, IEEE Computer Society, 2011.

[51] C. Xiu and K. K. Klein, "Melamine in milk products in China: examining the factors that led to deliberate use of the contaminant," Food Policy, vol. 35, no. 5, pp. 463-470, 2010.

[52] P. J. O'Mahony, "Finding horse meat in beef products-a global problem," QJM: An International Journal of Medicine, vol. 106, no. 6, pp. 595-597, 2013.

[53] K. Bonne and W. Verbeke, "Religious values informing halal meat production and the control and delivery of halal credence quality," Agriculture and Human Values, vol. 25, no. 1, pp. 35-47, 2008.

[54] M. Neufeld and J. Rehm, "Effectiveness of policy changes to reduce harm from unrecorded alcohol in Russia between 2005 and now," International Journal of Drug Policy, vol. 51, pp. 1-9, 2018.

[55] T. Kuballa, T. Hausler, A. O. Okaru et al., "Detection of counterfeit brand spirits using $1 \mathrm{H}$ NMR fingerprints in comparison to sensory analysis," Food Chemistry, vol. 245, pp. 112-118, 2018.

[56] M. V. de Moura Ribeiro, N. Boralle, H. Redigolo Pezza, L. Pezza, and A. T. Toci, "Authenticity of roasted coffee usinglH NMR 
spectroscopy," Journal of Food Composition and Analysis, vol. 57, pp. 24-30, 2017.

[57] A. T. Toci, A. Farah, H. R. Pezza, and L. Pezza, "Coffee Adulteration: More than Two Decades of Research," Critical Reviews in Analytical Chemistry, vol. 46, no. 2, pp. 83-92, 2016.

[58] E. Hong, S. Y. Lee, J. Y. Jeong et al., "Modern analytical methods for the detection of food fraud and adulteration by food category," Journal of the Science of Food and Agriculture, vol. 97, no. 12, pp. 3877-3896, 2017.

[59] P. K. Ghosh and D. S. Jayas, "Use of spectroscopic data for automation in food processing industry," Sensing and Instrumentation for Food Quality and Safety, vol. 3, no. 1, pp. 3-11, 2009.

[60] R. Karoui and J. De Baerdemaeker, "A review of the analytical methods coupled with chemometric tools for the determination of the quality and identity of dairy products," Food Chemistry, vol. 102, no. 3, pp. 621-640, 2007.

[61] L. Wang, D.-W. Sun, H. Pu, and J.-H. Cheng, "Quality analysis, classification, and authentication of liquid foods by nearinfrared spectroscopy: A review of recent research developments," Critical Reviews in Food Science and Nutrition, vol. 57, no. 7, pp. 1524-1538, 2017.

[62] C. A. Nunes, "Vibrational spectroscopy and chemometrics to assess authenticity, adulteration and intrinsic quality parameters of edible oils and fats," Food Research International, vol. 60, pp. 255-261, 2014.

[63] N. El Darra, H. N. Rajha, F. Saleh, R. Al-Oweini, R. G. Maroun, and N. Louka, "Food fraud detection in commercial pomegranate molasses syrups by UV-VIS spectroscopy, ATR-FTIR spectroscopy and HPLC methods," Food Control, vol. 78, pp. 132-137, 2017.

[64] K. M. Nunes, M. V. O. Andrade, A. M. P. Santos Filho, M. C. Lasmar, and M. M. Sena, "Detection and characterisation of frauds in bovine meat in natura by non-meat ingredient additions using data fusion of chemical parameters and ATR-FTIR spectroscopy," Food Chemistry, vol. 205, pp. 14-22, 2016.

[65] I. Kasprzyk, J. Depciuch, D. Grabek-Lejko, and M. ParlinskaWojtan, "FTIR-ATR spectroscopy of pollen and honey as a tool for unifloral honey authentication. The case study of rape honey," Food Control, vol. 84, pp. 33-40, 2018.

[66] E. A. Petrakis and M. G. Polissiou, "Assessing saffron (Crocus sativus L.) adulteration with plant-derived adulterants by diffuse reflectance infrared Fourier transform spectroscopy coupled with chemometrics," Talanta, vol. 162, pp. 558-566, 2017.

[67] A. Guelpa, F. Marini, A. du Plessis, R. Slabbert, and M. Manley, "Verification of authenticity and fraud detection in South African honey using NIR spectroscopy," Food Control, vol. 73, pp. 1388-1396, 2017.

[68] C. S. W. Miaw, C. Assis, A. R. Silva, M. L. Cunha, M. M. Sena, and S. V. de Souza, "Determination of main fruits in adulterated nectars by ATR-FTIR spectroscopy combined with multivariate calibration and variable selection methods," Food Chemistry, vol. 254, pp. 272-280, 2018.

[69] A. Galimberti, F. de Mattia, A. Losa et al., "DNA barcoding as a new tool for food traceability," Food Research International, vol. 50, no. 1, pp. 55-63, 2013.

[70] S. G. Newmaster, M. Grguric, D. Shanmughanandhan, S. Ramalingam, and S. Ragupathy, "DNA barcoding detects contamination and substitution in North American herbal products," BMC Medicine, vol. 11, no. 1, p. 222, 2013.

[71] B. A. Maralit, R. D. Aguila, M. F. H. Ventolero, S. K. L. Perez, D. A. Willette, and M. D. Santos, "Detection of mislabeled commercial fishery by-products in the Philippines using DNA barcodes and its implications to food traceability and safety," Food Control, vol. 33, no. 1, pp. 119-125, 2013.

[72] L. Guardone, L. Tinacci, F. Costanzo et al., "DNA barcoding as a tool for detecting mislabeling of fishery products imported from third countries: An official survey conducted at the Border Inspection Post of Livorno-Pisa (Italy)," Food Control, vol. 80, pp. 204-216, 2017.

[73] C. F. Staffen, M. D. Staffen, M. L. Becker et al., "DNA barcoding reveals the mislabeling of fish in a popular tourist destination in Brazil," PeerJ, vol. 5, Article ID e4006, 2017.

[74] R. S. Hellberg, B. C. Hernandez, and E. L. Hernandez, "Identification of meat and poultry species in food products using DNA barcoding," Food Control, vol. 80, pp. 23-28, 2017.

[75] Y. Liu, L. Xiang, Y. Zhang et al., "DNA barcoding based identification of Hippophae species and authentication of commercial products by high resolution melting analysis," Food Chemistry, vol. 242, pp. 62-67, 2018.

[76] M. Kokkonen, M. Jestoi, and A. Rizzo, "Determination of selected mycotoxins in mould cheeses with liquid chromatography coupled tandem with mass spectrometry," Food Additives \& Contaminants: Part A, vol. 22, no. 5, pp. 449-456, 2005.

[77] A. Soggiu, P. Roncada, and C. Piras, "Proteomics in Milk and Dairy Products," in Proteomics in Domestic Animals: from Farm to Systems Biology, pp. 169-193, Springer, Cham, Switherland, 2018.

[78] V. Di Stefano, G. Avellone, D. Bongiorno et al., "Applications of liquid chromatography-mass spectrometry for food analysis," Journal of Chromatography A, vol. 1259, pp. 74-85, 2012.

[79] R.-K. Chen, L.-W. Chang, Y.-Y. Chung, M.-H. Lee, and Y.-C. Ling, "Quantification of cow milk adulteration in goat milk using high-performance liquid chromatography with electrospray ionization mass spectrometry," Rapid Communications in Mass Spectrometry, vol. 18, no. 10, pp. 1167-1171, 2004.

[80] L. Muller, P. Barták, P. Bednář, I. Fryšová, J. Ševčík, and K. Lemr, "Capillary electrophoresis-mass spectrometry - A fast and reliable tool for the monitoring of milk adulteration," Electrophoresis, vol. 29, no. 10, pp. 2088-2093, 2008.

[81] D. Nardiello, A. Natale, C. Palermo, M. Quinto, and D. Centonze, "Milk authenticity by ion-trap proteomics following multi-enzyme digestion," Food Chemistry, vol. 244, pp. 317-323, 2018.

[82] T. Cajka, J. Hajslova, F. Pudil, and K. Riddellova, “Traceability of honey origin based on volatiles pattern processing by artificial neural networks," Journal of Chromatography A, vol. 1216, no. 9, pp. 1458-1462, 2009.

[83] T. Cajka, H. Danhelova, M. Zachariasova, K. Riddellova, and J. Hajslova, "Application of direct analysis in real time ionizationmass spectrometry (DART-MS) in chicken meat metabolomics aiming at the retrospective control of feed fraud," Metabolomics, vol. 9, no. 3, pp. 545-557, 2013.

[84] L. Vaclavik, V. Hrbek, T. Cajka, B.-A. Rohlik, P. Pipek, and J. Hajslova, "Authentication of animal fats using direct analysis in real time (DART) ionization-mass spectrometry and chemometric tools," Journal of Agricultural and Food Chemistry, vol. 59, no. 11, pp. 5919-5926, 2011.

[85] T. Cajka, K. Riddellova, M. Tomaniova, and J. Hajslova, "Ambient mass spectrometry employing a DART ion source for metabolomic fingerprinting/profiling: A powerful tool for beer origin recognition," Metabolomics, vol. 7, no. 4, pp. 500-508, 2011. 
[86] L. Vaclavik, T. Cajka, V. Hrbek, and J. Hajslova, "Ambient mass spectrometry employing direct analysis in real time (DART) ion source for olive oil quality and authenticity assessment," Analytica Chimica Acta, vol. 645, no. 1-2, pp. 56-63, 2009.

[87] V. Hrbek, L. Vaclavik, O. Elich, and J. Hajslova, "Authentication of milk and milk-based foods by direct analysis in real time ionization-high resolution mass spectrometry (DART-HRMS) technique: A critical assessment," Food Control, vol. 36, no. 1, pp. 138-145, 2014.

[88] B. Avula, T. J. Smillie, Y.-H. Wang, J. Zweigenbaum, and I. A. Khan, "Authentication of true cinnamon (Cinnamon verum) utilising direct analysis in real time (DART)-QToF-MS," Food Additives and Contaminants - Part A Chemistry, Analysis, Control, Exposure and Risk Assessment, vol. 32, no. 1, pp. 1-8, 2015.

[89] H. H. Grundy, S. D. Kelly, A. J. Charlton et al., "Food authenticity and food fraud research: achievements and emerging issues," Journal of the Association of Public Analysts, vol. 40, pp. 65-68, 2012 (Chinese).

[90] I. Martinez and T. J. Friis, "Application of proteome analysis to seafood authentication," Proteomics, vol. 4, no. 2, pp. 347-354, 2004.

[91] Council Regulation (EEC) No. 104/2000 on the common organization of the markets in fishery and aquaculture products.

[92] S. Charlebois, B. Sterling, S. Haratifar, and S. K. Naing, "Comparison of Global Food Traceability Regulations and Requirements," Comprehensive Reviews in Food Science and Food Safety, vol. 13, no. 5, pp. 1104-1123, 2014.

[93] Regulation (EU) No 1169/2011 of the European Parliament and of the Council of 25 October 2011 on the provision of food information to consumers, amending Regulations (EC) No 1924/2006 and (EC) No 1925/2006 of the European Parliament and of the Council.

[94] Regulation (EU) No 1379/2013 of the European Parliament and of the Council of 11 December 2013 on the common organisation of the markets in fishery and aquaculture products, amending Council Regulations (EC) No 1184/2006 and (EC) No $1224 / 2009$.

[95] K. Kappel and U. Schröder, "Substitution of high-priced fish with low-priced species: Adulteration of common sole in German restaurants," Food Control, vol. 59, pp. 478-486, 2016.

[96] Commission recommendation 1558 of 12.3 .2015 on a coordinated control plan with a view to establishing the prevalence of fraudulent practices in the marketing of certain foods.

[97] C. G. Sotelo, C. Piñeiro, J. M. Gallardo, and R. I. Pérez-Martin, "Fish species identification in seafood products," Trends in Food Science \& Technology, vol. 4, no. 12, pp. 395-401, 1993.

[98] T. Civera, "Species identification and safety of fish products," Veterinary Research Communications, vol. 27, no. 1, pp. 481-489, 2003.

[99] V. M. Moretti, G. M. Turchini, F. Bellagamba, and F. Caprino, "Traceability issues in fishery and aquaculture products," Veterinary Research Communications, vol. 27, no. 1, pp. 497-505, 2003.

[100] J. A. Lenstra, "DNA methods for identifying plant and animal species in food," Food Authenticity and Traceability, pp. 34-53, 2013.

[101] C. De Battisti, S. Marciano, C. Magnabosco, S. Busato, G. Arcangeli, and G. Cattoli, "Pyrosequencing as a tool for rapid fish species identification and commercial fraud detection," Journal of Agricultural and Food Chemistry, vol. 62, no. 1, pp. 198-205, 2014.
[102] M. Kochzius, C. Seidel, A. Antoniou, S. K. Botla et al., "Identifying fishes through DNA barcodes and microarrays," PLoS One, vol. 5, no. 9, Article ID e12620, 2010.

[103] Z. J. Liu and J. F. Cordes, "DNA marker technologies and their applications in aquaculture genetics," Aquaculture, vol. 238, no. 1-4, pp. 1-37, 2004.

[104] J. J. Dooley, H. D. Sage, H. M. Brown, and S. D. Garrett, "Improved fish species identification by use of lab-on-a-chip technology," Food Control, vol. 16, no. 7, pp. 601-607, 2005.

[105] H.-S. Hsieh, T.-J. Chai, and D.-F. Hwang, "Using the PCR-RFLP method to identify the species of different processed products of billfish meats," Food Control, vol. 18, no. 4, pp. 369-374, 2007.

[106] W.-F. Lin and D.-F. Hwang, "Application of PCR-RFLP analysis on species identification of canned tuna," Food Control, vol. 18, no. 9, pp. 1050-1057, 2007.

[107] M. Jérôme, C. Lemaire, V. Verrez-Bagnis, and M. Etienne, "Direct Sequencing Method for Species Identification of Canned Sardine and Sardine-Type Products," Journal of Agricultural and Food Chemistry, vol. 51, no. 25, pp. 7326-7332, 2003.

[108] F. J. Santaclara, A. G. Cabado, and J. M. Vieites, "Development of a method for genetic identification of four species of anchovies: E. encrasicolus, E. anchoita, E. ringens and E. japonicus," European Food Research and Technology, vol. 223, no. 5, pp. 609-614, 2006.

[109] Y.-S. Lin, Y.-P. Poh, S.-M. Lin, and C.-S. Tzeng, "Molecular techniques to identify freshwater eels: RFLP analyses of PCRamplified DNA fragments and allele-specific PCR from mitochondrial DNA," Zoological Studies-Taipei-, vol. 41, no. 4, pp. 421-430, 2002.

[110] I. Rego, A. Martínez, A. González-Tizón, J. Vieites, F. Leira, and J. Méndez, "PCR technique for identification of mussel species," Journal of Agricultural and Food Chemistry, vol. 50, no. 7, pp. 1780-1784, 2002.

[111] S. Klinbunga, P. Pripue, N. Khamnamtong et al., "Genetic Diversity and Molecular Markers of the Tropical Abalone (Haliotis asinina) in Thailand," Marine Biotechnology, vol. 5, no. 5, pp. 505-517, 2003.

[112] I. Calves, E. Lavergne, A. L. Meistertzheim et al., "Genetic structure of European flounder Platichthys flesus: Effects of both the southern limit of the species' range and chemical stress," Marine Ecology Progress Series, vol. 472, pp. 257-273, 2013.

[113] I. Coscia, P. E. Robins, J. S. Porter, S. K. Malham, and J. E. Ironside, "Modelled larval dispersal and measured gene flow: Seascape genetics of the common cockle Cerastoderma edule in the southern Irish Sea," Conservation Genetics, vol. 14, no. 2, pp. 451-466, 2013.

[114] N. L. Tatsadjieu, J. Maïworé, M. B. Hadjia, G. Loiseau, D. Montet, and C. M. F. Mbofung, "Study of the microbial diversity of Oreochromis niloticus of three lakes of Cameroon by PCRDGGE: Application to the determination of the geographical origin," Food Control, vol. 21, no. 5, pp. 673-678, 2010.

[115] D. Montet, D. D. Le Nguyen, A. El Sheikha, A. Condur, I. Metayer, and G. Loiseau, "Application of PCR-DGGE in determining food origin: Cases studies of fish and fruits," Aspects of Applied Biology, vol. 87, pp. 11-22, 2008.

[116] D. D. Le Nguyen, H. H. Ngoc, D. Dijoux, G. Loiseau, and D. Montet, "Determination of fish origin by using 16S rDNA fingerprinting of bacterial communities by PCR-DGGE: An application on Pangasius fish from Viet Nam," Food Control, vol. 19, no. 5, pp. 454-460, 2008.

[117] M. B. Hovda, M. Sivertsvik, B. Tore Lunestad, G. Lorentzen, and J. T. Rosnes, "Characterisation of the dominant bacterial 
population in modified atmosphere packaged farmed halibut (Hippoglossus hippoglossus) based on 16S rDNA-DGGE," Food Microbiology, vol. 24, no. 4, pp. 362-371, 2007.

[118] H. S. Carson, P. C. López-Duarte, G. S. Cook et al., “Temporal, spatial, and interspecific variation in geochemical signatures within fish otoliths, bivalve larval shells, and crustacean larvae," Marine Ecology Progress Series, vol. 473, pp. 133-148, 2013.

[119] P. Reis-Santos, B. M. Gillanders, S. E. Tanner, R. P. Vasconcelos, T. S. Elsdon, and H. N. Cabral, "Temporal variability in estuarine fish otolith elemental fingerprints: Implications for connectivity assessments," Estuarine, Coastal and Shelf Science, vol. 112, pp. 216-224, 2012.

[120] C. J. B. Sorte, R. J. Etter, R. Spackman, E. E. Boyle, and R. E. Hannigan, "Elemental fingerprinting of mussel shells to predict population sources and redistribution potential in the Gulf of Maine," PLoS ONE, vol. 8, no. 11, Article ID e80868, 2013.

[121] G. D’Avignon and G. A. Rose, "Otolith elemental fingerprints distinguish Atlantic cod spawning areas in Newfoundland and Labrador," Fisheries Research, vol. 147, pp. 1-9, 2013.

[122] B. J. Broadaway and R. E. Hannigan, "Elemental fingerprints used to identify essential habitats: Nantucket bay scallop," Journal of Shellfish Research, vol. 31, no. 3, pp. 671-676, 2012.

[123] G. Smulevich, E. Droghetti, C. Focardi, M. Coletta, C. Ciaccio, and M. Nocentini, "A rapid spectroscopic method to detect the fraudulent treatment of tuna fish with carbon monoxide," Food Chemistry, vol. 101, no. 3, pp. 1071-1077, 2007.

[124] J. P. Bergé and G. Barnathan, "Fatty acids from lipids of marine organisms: molecular biodiversity, roles as biomarkers, biologically active compounds, and economical aspects," in Marine biotechnology I, vol. 96, pp. 49-125, Springer, Berlin, Germany, 2005.

[125] J. M. Hall, C. C. Parrish, and R. J. Thompson, "Eicosapentaenoic acid regulates scallop (Placopecten magellanicus) membrane fluidity in response to cold," The Biological Bulletin, vol. 202, no. 3, pp. 201-203, 2002.

[126] R. Rosa, L. Gonzalez, B. R. Broitman, S. Garrido, A. M. P. Santos, and M. L. Nunes, "Bioenergetics of small pelagic fishes in upwelling systems: Relationship between fish condition, coastal ecosystem dynamics and fisheries," Marine Ecology Progress Series, vol. 410, pp. 205-218, 2010.

[127] J. R. Kelly and R. E. Scheibling, "Fatty acids as dietary tracers in benthic food webs," Marine Ecology Progress Series, vol. 446, pp. $1-22,2012$.

[128] S. Masoum, C. Malabat, M. Jalali-Heravi, C. Guillou, S. Rezzi, and D. N. Rutledge, "Application of support vector machines to $1 \mathrm{H}$ NMR data of fish oils: Methodology for the confirmation of wild and farmed salmon and their origins," Analytical and Bioanalytical Chemistry, vol. 387, no. 4, pp. 1499-1510, 2007.

[129] D. E. Axelson, I. B. Standal, I. Martinez, and M. Aursand, "Classification of wild and farmed salmon using Bayesian belief networks and gas chromatography-derived fatty acid distributions," Journal of Agricultural and Food Chemistry, vol. 57, no. 17, pp. 7634-7639, 2009.

[130] O. Grahl-Nielsen, A. Jacobsen, G. Christophersen, and T. Magnesen, "Fatty acid composition in adductor muscle of juvenile scallops (Pecten maximus) from five Norwegian populations reared in the same environment," Biochemical Systematics and Ecology, vol. 38, no. 4, pp. 478-488, 2010.

[131] B. R. Olsen, O. Grahl-Nielsen, and C. Schander, "Population study of Astarte sulcata, da Costa, 1778, (Mollusca, Bivalvia) from two Norwegian fjords based on the fatty acid composition of the adductor muscle," Biochemical Systematics and Ecology, vol. 37, no. 5, pp. 662-669, 2009.

[132] M. Aursand, I. B. Standal, A. Praël, L. Mcevoy, J. Irvine, and D. E. Axelson, "13C NMR pattern recognition techniques for the classification of atlantic salmon (salmo salar L.) according to their wild, farmed, and geographical origin," Journal of Agricultural and Food Chemistry, vol. 57, no. 9, pp. 3444-3451, 2009.

[133] K. A. Anderson, K. A. Hobbie, and B. W. Smith, "Chemical profiling with modeling differentiates wild and farm-raised salmon." Journal of Agricultural and Food Chemistry, vol. 58, no. 22, pp. 11768-11774, 2010.

[134] M. Forina, P. Oliveri, S. Lanteri, and M. Casale, "Class-modeling techniques, classic and new, for old and new problems," Chemometrics and Intelligent Laboratory Systems, vol. 93, no. 2, pp. 132148, 2008.

[135] P. Oliveri and G. Downey, "Multivariate class modeling for the verification of food-authenticity claims," TrAC - Trends in Analytical Chemistry, vol. 35, pp. 74-86, 2012.

[136] S. Wold and M. Sjostrom, "SIMCA: A Method for Analyzing Chemical Data in Terms of Similarity and Analogy," in Chemometrics: Theory and Applications, ACS Symp, B. R. Kowalski, Ed., vol. 52, pp. 243-282, American Chemical Society, Washington, Wash, USA, 1977.

[137] M. P. Derde and D. L. Massart, "UNEQ: a disjoint modelling technique for pattern recognition based on normal distribution," Analytica Chimica Acta, vol. 184, pp. 33-51, 1986.

[138] M. Forina, C. Armanino, R. Leardi, and G. Drava, "A classmodelling technique based on potential functions," Journal of Chemometrics, vol. 5, no. 5, pp. 435-453, 1991.

[139] M. P. Callao and I. Ruisanchez, "An overview of multivariate qualitative methods for food fraud detection," Food Control, vol. 86, pp. 283-293, 2018.

[140] L. Kuuliala, E. Abatih, A.-G. Ioannidis et al., "Multivariate statistical analysis for the identification of potential seafood spoilage indicators," Food Control, vol. 84, pp. 49-60, 2018. 


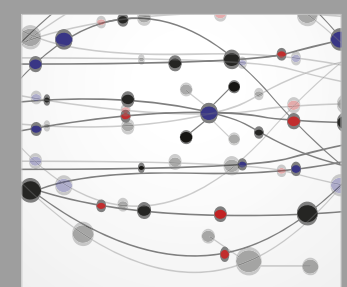

The Scientific World Journal
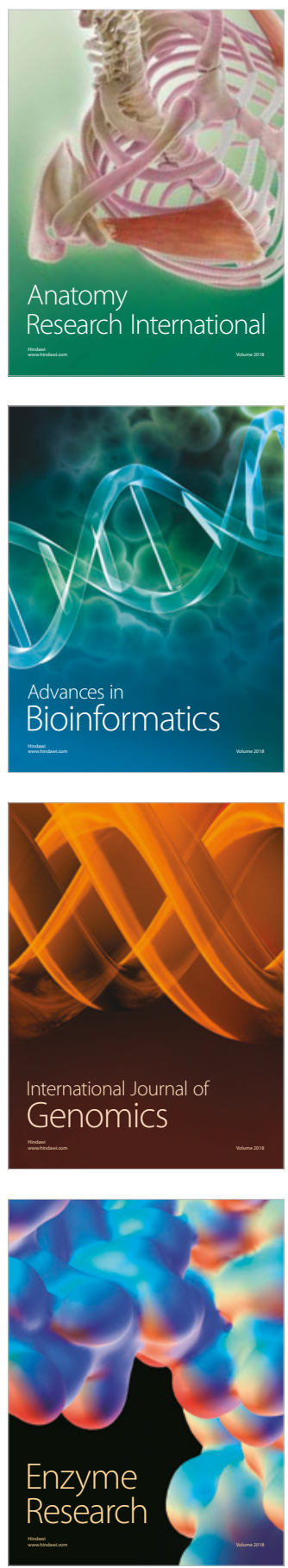
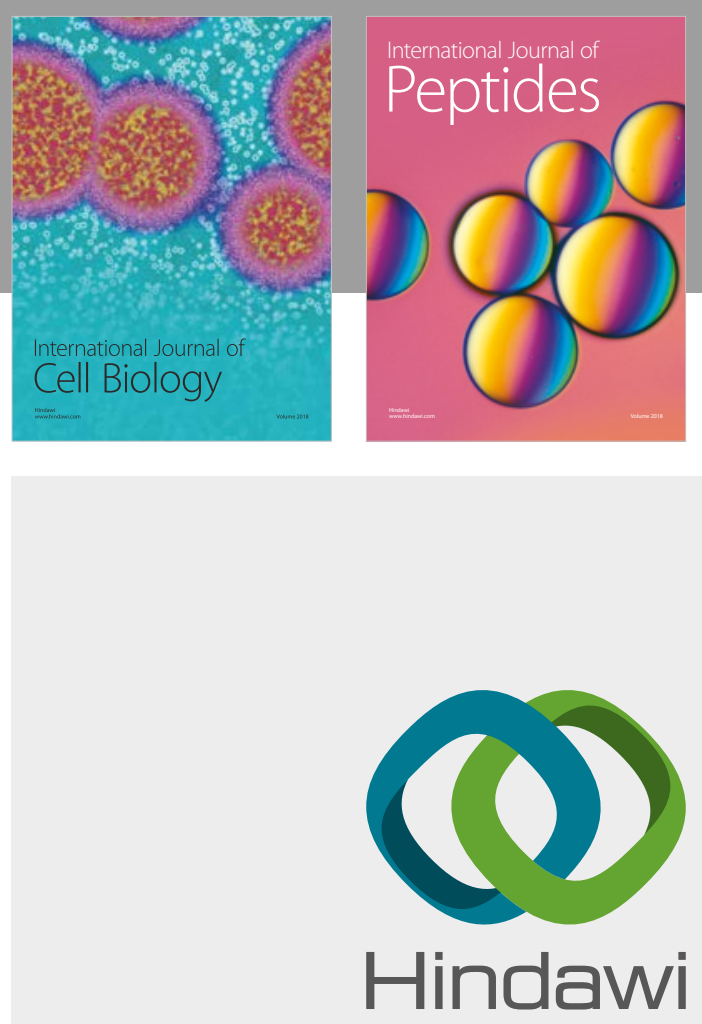

Submit your manuscripts at

www.hindawi.com
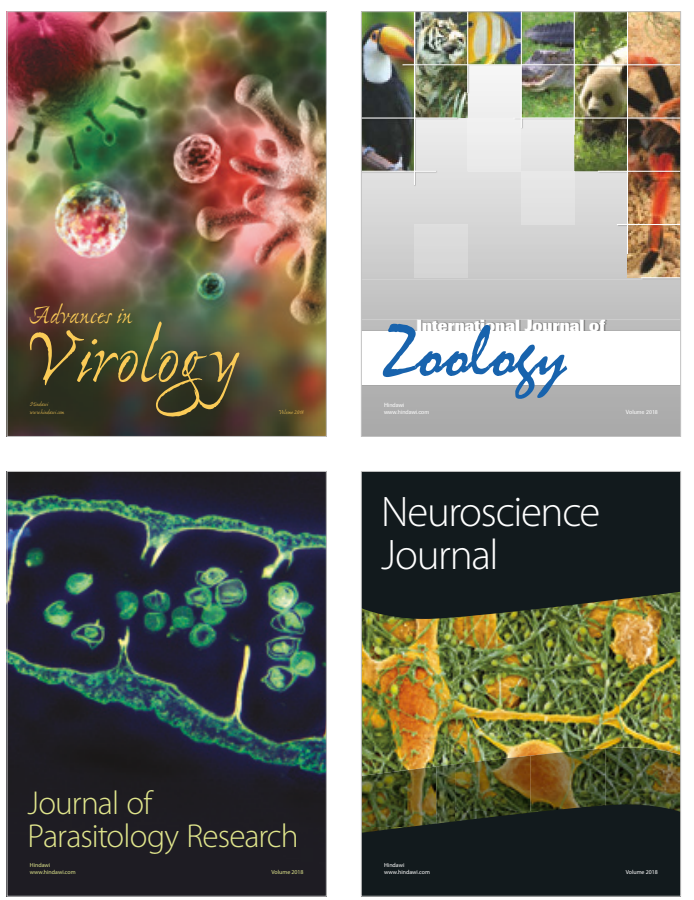
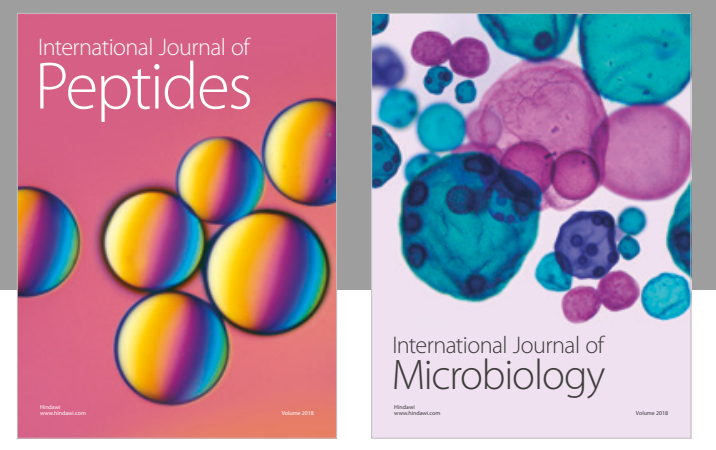

nternational Journal of Microbiology
Journal of
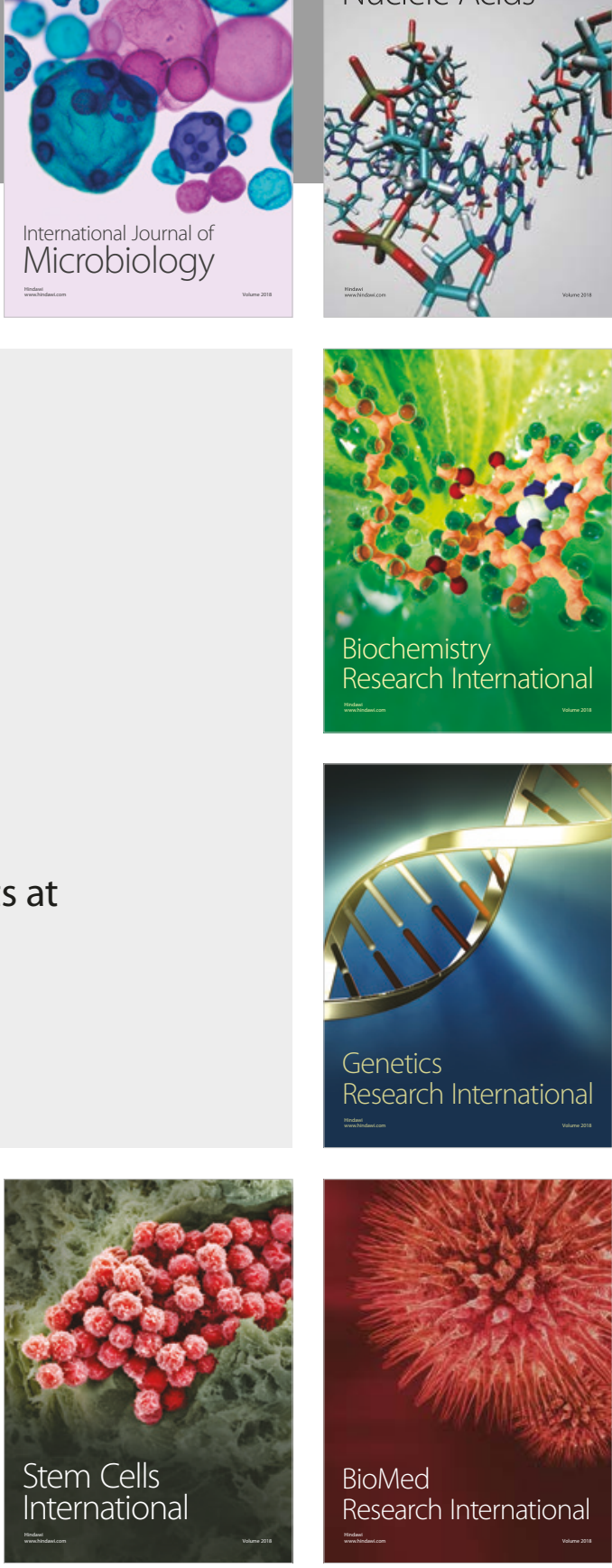
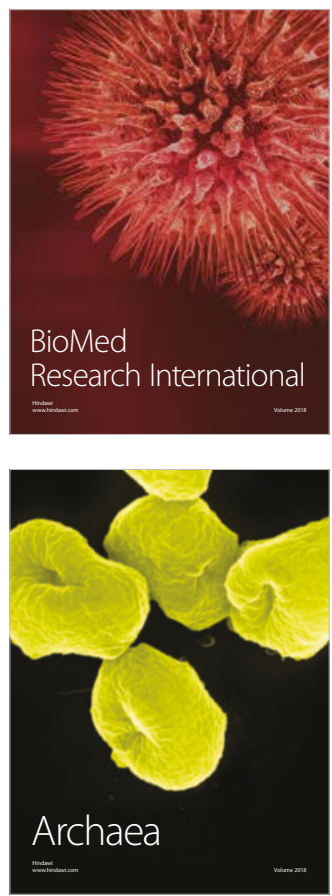